\title{
Aircraft measurements of nitrogen oxides, ozone, and carbon monoxide during MINOS 2001: distributions and correlation analyses
}

\author{
J. Heland ${ }^{1}$, H. Ziereis ${ }^{1}$, H. Schlager ${ }^{1}$, M. de Reus ${ }^{2}$, M. Traub ${ }^{2}$, J. Lelieveld ${ }^{2}$, \\ G.-J. Roelofs ${ }^{3}$, P. Stock ${ }^{1}$, and A. Roiger ${ }^{1}$ \\ ${ }^{1}$ Deutsches Zentrum für Luft- und Raumfahrt (DLR), Oberpfaffenhofen, Germany \\ ${ }^{2}$ Max-Planck-Institute for Chemistry (MPI-CH), Mainz, Germany \\ ${ }^{3}$ Institute for Marine and Atmospheric Research Utrecht (IMAU), Utrecht University, Utrecht, \\ The Netherlands
}

Received: 31 January 2003 - Accepted: 27 March 2003 - Published: 15 April 2003

Correspondence to: J. Heland (joerg.heland@dlr.de)

\begin{abstract}
We present mean altitude profiles of $\mathrm{NO}_{\mathrm{x}}, \mathrm{NO}_{\mathrm{y}}, \mathrm{O}_{3}$, and $\mathrm{CO}$ as measured by the DLR Falcon aircraft during the MINOS 2001 campaign over the Mediterranean in August 2001 and compare the data with results from other aircraft campaigns, namely the SIL 51996 (North Atlantic flight corridor), the POLINAT-2 (North Atlantic flight corridor), and the EXPORT 2000 (central Europe) campaigns. The MINOS NO, $\mathrm{O}_{3}$, and $\mathrm{CO}$ mixing ratios in the free troposphere, especially between $4-8 \mathrm{~km}$, are very similar to those measured during the EXPORT 2000 campaign. However, compared to the other campaigns the MINOS $\mathrm{O}_{3}$ and $\mathrm{CO}$ were significantly higher in the boundary layer, by about $1020 \mathrm{ppbV}$ and $50 \mathrm{ppbV}$, respectively. In the second part of the paper the $\Delta\left[\mathrm{O}_{3}\right] / \Delta\left[\mathrm{NO}_{\mathrm{y}}\right]$, $\Delta\left[\mathrm{O}_{3}\right] / \Delta[\mathrm{CO}], \Delta[\mathrm{CO}] / \Delta\left[\mathrm{NO}_{\mathrm{y}}\right]$, and $\Delta\left[\mathrm{NO}_{\mathrm{x}}\right] / \Delta\left[\mathrm{NO}_{\mathrm{y}}\right]$ trace gas correlations were calculated for the MINOS 2001 campaign. It was found that, within the scatter of the data, the overall average altitude profiles of the correlations compared well with data from a literature survey. The analysis of the mean vertical correlation profiles as measured 15 during MINOS 2001 does therefore not single out special meteorological conditions and air mass origins over the Mediterranean in summer but reflects a more general condition of the free troposphere in the northern hemisphere. Correlation analyses for single flights at different altitudes, however, unambiguously identify air masses influenced by the stratosphere, whereas pollution plumes could only be identified with the help of back trajectories.
\end{abstract}

\section{Introduction}

Extensive measurements of trace gases and aerosol parameters were performed on board the DLR research aircraft Falcon during the Mediterranean Intensive Oxidant Study (MINOS) over the eastern Mediterranean Sea out of Heraklion, Crete, in August 2001. The objective of the MINOS campaign was to study the main processes involved in the Mediterranean pollution build-up, i.e. (a) the transport of pollution from 
Europe and from remote sources, (b) the chemical mechanisms that contribute to the build-up of oxidants and aerosols, and (c) the export of pollutants to the global environment, e.g. towards south-east Asia, see also Lelieveld et al. (2002), and http://www.mpch-mainz.mpg.de/ reus/minos/. During the campaign fourteen mea-

5 surement flights plus ferry flights from and to Germany were made, comprising measurements of e.g. $\mathrm{NO}, \mathrm{NO}_{\mathrm{y}}\left(=\mathrm{NO}+\mathrm{NO}_{2}+\mathrm{HNO}_{3}+\mathrm{HONO}+\mathrm{PAN}+\mathrm{NO}_{3}+\ldots\right), \mathrm{O}_{3}, \mathrm{~J}\left(\mathrm{NO}_{2}\right)$, $\mathrm{CO}, \mathrm{CH}_{4}, \mathrm{CO}_{2}$, PAN, aerosol parameters, selected carbonyl compounds, alcohols, and hydrocarbons. Supplementary ground-based observations were made during the campaign from Finokalia, Crete.

10 In an overview of MINOS, presented in Lelieveld et al. (2002) air pollution in different altitude regimes over the Mediterranean in summer was traced to several source regions, see also Millan et al. (1997, 2002). While the boundary layer is mainly influenced by northerly winds carrying West- and East-European emissions, the composition of the free troposphere is dominated by a mixture of Asian, North Atlantic, and North

15 American air masses from the west. In the upper troposphere outflow from the Asian monsoon is brought into the Mediterranean from the east. This is also illustrated in Fig. 1 which shows a qualitative analysis of the air mass origins as an altitude plot over Crete during August 2001, based on the 6-hourly output from model runs with ECHAM4 (T63) (Roelofs et al., this issue). The "lifetime" of the color encoded idealized tracers was set to 14 days. It should be noted that the contour lines in Fig. 1 are arbitrary and give no information about total values of tracers. According to the model results the overall picture of the origins in August 2001 suggests a strong influence of European pollution (yellow) on the Crete planetary boundary layer (PLB) up to about $2 \mathrm{~km}$ altitude. In the free troposphere $(\approx 3-8 \mathrm{~km})$ a layer with tracers of stratospheric origin (blue) is mixed with North American (red) and North Atlantic (green) tracers. During most of the campaign the upper tropospheric air was found to be strongly influenced by monsoon outflow being uplifted from the PBL over Asia (orange). This very sharp layering weakened after 15 August 2001, and eventually broke up until the end of the campaign, see also Roelofs et al., this issue.

1993

One of the main objectives of this paper is to present and discuss mean vertical profiles of (a) the trace gas mixing ratios and (b) the trace gas correlations derived from the MINOS 2001 aircraft dataset, in support of the analysis of trace gas source regions and types.

5 Mean altitude profiles of the $\mathrm{NO}_{x}, \mathrm{NO}_{y}, \mathrm{O}_{3}$, and $\mathrm{CO}$ volume mixing ratios measured during the fourteen MINOS 2001 flights will be shown in Sect. 3.1. These data will be discussed and compared with data from former studies, i.e. the SIL 1996 ("Schadstoffe in der Luftfahrt"), the POLINAT-2 ("Pollution from Aircraft in the North Atlantic Flight Corridor"), and the EXPORT 2000 campaigns which were carried out in other regions 10 and during different seasons.

In Sect. 3.2 the $\Delta\left[\mathrm{O}_{3}\right] / \Delta\left[\mathrm{NO}_{\mathrm{y}}\right], \Delta\left[\mathrm{O}_{3}\right] / \Delta[\mathrm{CO}], \Delta[\mathrm{CO}] / \Delta\left[\mathrm{NO}_{\mathrm{y}}\right]$, and $\left[\mathrm{NO}_{\mathrm{x}}\right] / \Delta\left[\mathrm{NO}_{\mathrm{y}}\right]$ correlations obtained during MINOS 2001 will be analysed. These correlations refer to (a) mean altitude profiles during the campaign, and (b) single observed plumes, along the flight tracks as time series, and as altitude profiles from single measurement flights.

15 Case studies of single flights together with back trajectory analyses will be shown in this section. Finally, the MINOS 2001 correlations will be compared with data from earlier studies.

\section{Experimental}

The in situ aircraft measurements of $\mathrm{NO}, \mathrm{NO}_{\mathrm{y}}$, the photolysis frequency of $\mathrm{NO}_{2}\left(\mathrm{JNO}_{2}\right)$, ozone (DLR), carbon monoxide (MPI-CH), and the meteorological parameters (DLR) during MINOS 2001 were performed on board the DLR Falcon. Detailed descriptions of the equipment are reported elsewhere (Ziereis et al., 1999, 2000a, 2000b; Junkermann et al., 1989, Volz-Thomas et al., 1996; Wienhold et al., 1998).

Briefly, NO is measured with a well characterized chemiluminescence detector 25 (CLD). $\mathrm{NO}_{\mathrm{y}}$ is measured with a second CLD in combination with an Au converter heated to $300^{\circ} \mathrm{C}$ with $\mathrm{CO}(0.2 \%)$ as the reduction agent. Calibration of the CLDs is performed before the flights using a diluted mixture of $2.97 \mathrm{ppmV} \pm 1 \% \mathrm{NO}$ in $\mathrm{N}_{2}$ 
(Messer-Griesheim) with purified air. The pressure dependent efficiency of the $\mathrm{NO}_{\mathrm{y}}$ conversion is determined with a known amount of $\mathrm{NO}_{2}$ generated from gas phase titration of $\mathrm{NO}$ with $\mathrm{O}_{3}$ and is $0.92-0.99$ for the pressure range discussed in this study. The detection limits of the instruments are $5 \mathrm{pptV}$ for $\mathrm{NO}$, and $15 \mathrm{pptV}$ for $\mathrm{NO}_{\mathrm{y}}$. The

5 accuracies of the measurements are $5 \%$ and $12 \%$ for $\mathrm{NO}$ and $\mathrm{NO}_{\mathrm{y}}$, respectively.

The photolysis frequency $\mathrm{J}\left(\mathrm{NO}_{2}\right)$ is obtained from the sum of two filter radiometers (Meteo Consult $\mathrm{GmbH}$ ) with $2 \pi$ viewing geometry. One of the radiometers is installed on top of the aircraft, the second on the downward facing side of the aircraft body. The detectors have been optimized for flight applications (Volz-Thomas et al., 1996)

10 and have recently been characterized in our laboratory (Hauser, 2002). The overall uncertainty of the $\mathrm{J}\left(\mathrm{NO}_{2}\right)$ measurements is about $17 \%$.

To obtain the $\mathrm{NO}_{\mathrm{x}}\left(=\mathrm{NO}+\mathrm{NO}_{2}\right)$ mixing ratios the $\mathrm{NO}_{2}$ concentrations were computed assuming simple photostationary steady state conditions (e.g. Leighton 1961; Atkinson 2000)

$\left[\mathrm{NO}_{2}\right]=\frac{k\left(\mathrm{NO}+\mathrm{O}_{3}\right)}{\mathrm{J}\left(\mathrm{NO}_{2}\right)} \times[\mathrm{NO}] \times\left[\mathrm{O}_{3}\right]$

where the temperature dependent reaction rate coefficient $k\left(\mathrm{NO}+\mathrm{O}_{3}\right)$ was calculated from the data given in Sander et al. (2000). The overall uncertainty of the nitrogen dioxide mixing ratios depends on the experimental uncertainties of $\mathrm{NO}$ and $\mathrm{O}_{3}, \mathrm{~J}\left(\mathrm{NO}_{2}\right)$, $k\left(\mathrm{NO}+\mathrm{O}_{3}\right)$, and on the unknown amount of $\mathrm{NO}_{2}$ produced by molecules other than $20 \mathrm{O}_{3}$ (e.g. RO2) and is estimated to be about $25 \%$.

UV-absorption measurements of ozone were performed with a modified TE 49 instrument (Thermo Environmental) calibrated with a $\mathrm{O}_{3} 41 \mathrm{M}$ ozone generator (ANSYCO) which is frequently calibrated against a standard device from the Global Atmosphere Watch system (GAW) (http://www.wmo.ch). The accuracy of the ozone measurements 25 is $5 \%$, the time resolution is $4 \mathrm{~s}$.

Carbon monoxide measurements were performed using a tunable diode laser (TDLAS) instrument with a precision of $1.5 \mathrm{ppbV}(1 \sigma)$ and a calibration accuracy of $1.5 \%$

1995

for $1 \mathrm{~s}$ integration times (Wienhold et al., 1998). Since the TDLAS measured two additional trace gases with approximately the same time resolution the $\mathrm{CO}$ data were obtained every 4-6s.

To reduce the number of experimental data and to obtain a dataset on the same time 5 scale $10 \mathrm{~s}$ averages of all quantities were calculated.

\section{Results and discussion}

\subsection{Altitude profiles of trace gases}

\subsubsection{Altitude profiles of $\mathrm{NO}_{\mathrm{x}}, \mathrm{NO}_{\mathrm{y}}, \mathrm{O}_{3}$, and $\mathrm{CO}$ measured during MINOS 2001}

The mean altitude profiles of $\mathrm{NO}_{\mathrm{x}}, \mathrm{NO}_{\mathrm{y}}, \mathrm{O}_{3}$ and $\mathrm{CO}$ measured during the 14 MINOS 10 flights are shown in Fig. 2. The averaged tropospheric data (defined as $\mathrm{O}_{3}<160 \mathrm{ppbV}$ ) including 1 standard deviation $( \pm 1 \sigma)$ are plotted. The highly variable $\mathrm{NO}_{\mathrm{x}}$ data in the boundary layer with average volume mixing ratios (VMR) of about $0.4 \mathrm{ppbV}$ decrease with altitude to about $(0.04 \pm 0.03) \mathrm{ppbV}$ in the free troposphere between $4-8 \mathrm{~km}$. Above $8 \mathrm{~km}$ altitude the $\mathrm{NO}_{\mathrm{x}}$ VMR increases again. Mean $\mathrm{NO}_{\mathrm{y}}$ VMRs in the boundary layer were about $(1.5 \pm 1.0)$ ppbV during the MINOS campaign. These data decrease with increasing altitude to about $(0.5 \pm 0.4) \mathrm{ppbV}$ in the free troposphere and increase again slightly towards the tropopause. The average $\mathrm{O}_{3}$ mixing ratios measured during the MINOS campaign up to about $8 \mathrm{~km}$ altitude range between 60 and $80 \mathrm{ppbV}$ and increase slightly at higher altitudes. The mean VMRs of $\mathrm{CO}$ decrease from roughly $20(150 \pm 30) \mathrm{ppbV}$ in the boundary layer to $(100 \pm 20) \mathrm{ppbV}$ at $4 \mathrm{~km}$ altitude. From the lower to the upper free troposphere the CO VMRs slightly decrease from approximately $100 \mathrm{ppbV}$.

According to the classification presented in Emmons et al. (2000) the shapes of the $\mathrm{NO}_{\mathrm{x}}, \mathrm{O}_{3}$ and $\mathrm{CO}$ profiles measured during MINOS 2001 resemble those influenced by 25 industrial pollution and/or biomass burning. 
To reveal differences and similarities of the MINOS 2001 dataset with other northern extratropical campaigns, i.e. under different pollution levels in the Atlantic and European continental region, the MINOS data from the troposphere were compared with

5 tropospheric data from earlier campaigns. The campaigns used for the comparison are

(a) the SIL 1996 campaign of the German national programme "Schadstoffe in der Luftfahrt" (SIL 1996) (e.g. Schumann 1998, 2002) in which data were sampled in the North American flight corridor based out of Prestwick, Scotland (Ziereis et al., 1999).

(b) the POLINAT-2 campaign with 14 flights conducted in September/October 1997 from Shannon, Ireland, with the main focus to study the impact of air traffic on the composition of the atmosphere at altitudes between 9 and $13 \mathrm{~km}$ (Ziereis et al., 2000a; Schlager et al., 1999; Schumann et al., 2000, http://www.pa.op.dlr.de/ polinat).

(c) the DLR EXPORT 2000 campaign with 9 flights based out of Oberpfaffenhofen, Germany, in July/August 2000 over central Europe with the aim to study the export of pollutants out of source regions over Europe.

The direct comparison of the $\mathrm{NO}_{x}, \mathrm{NO}_{\mathrm{y}}, \mathrm{O}_{3}$, and $\mathrm{CO}$ profiles is shown in Fig. 3. To

obtain a clearer picture of the comparison, the MINOS data are plotted as the average values with the corresponding standard deviations, whereas for the other campaigns only the averages are printed. It will be highlighted in the text whenever very high or low standard deviations were observed.

$\mathrm{NO}_{\mathbf{x}}$ (Fig. 3A). At first glance the observed $\mathrm{NO}_{\mathrm{x}}$ VMRs from the EXPORT 2000 25 campaign seem to be higher than the data from all other campaigns. However the EXPORT 2000 data up to about $6 \mathrm{~km}$ altitude do also show strong variations and the

$1 \sigma$ standard deviations (not shown in the plot) are extremely high and close to $100 \%$ of the absolute values. This indicates extreme variations of the $\mathrm{NO}_{\mathrm{x}}$ mixing ratios due to fresh emissions and convection over central Europe in summer. Comparing the POLINAT-2 and SIL $1996 \mathrm{NO}_{x}$ profiles with the MINOS data reveals that the MINOS $5 \mathrm{NO}_{\mathrm{x}}$ VMRs are slightly higher above $\approx 8-10 \mathrm{~km}$. Again, according to the classification given in Emmons et al. (2000) the profiles from both datasets, EXPORT 2000 and MINOS 2001, can be best described as "profiles influenced by industrial emissions and/or biomass burning".

$\mathrm{NO}_{\mathrm{y}}$ (Fig. 3B). In contrast to the high variability of the $\mathrm{NO}_{\mathrm{x}}$ data the EXPORT 2000 10 $\mathrm{NO}_{y}$ data are smoother and exhibit lower standard deviations (not shown). However, the average total $\mathrm{NO}_{y}$ profiles from these campaigns are almost identical to the MINOS data, at least up to altitudes of about $8 \mathrm{~km}$. This shows, that despite of the different airmass origins and transport times during the different campaigns, the average volume mixing ratios at different altitudes are very similar. However, compared to the MINOS data the POLINAT-2 $\mathrm{NO}_{\mathrm{y}}$ data are almost $0.5 \mathrm{ppbV}$ lower in the upper troposphere.

$\mathbf{O}_{3}$ (Fig. 3C). Compared to the other campaigns the mean MINOS ozone mixing ratios are approximately 10-20 ppbV higher in the lower troposphere, but are similar to the measurements during EXPORT 2000 in the upper troposphere. The SIL 1996 and POLINAT-2 datasets indicate about $20 \mathrm{ppbV}$ lower ozone values in the middle and up20 per troposphere up to altitudes of about $11 \mathrm{~km}$. According to Emmons et al. (2000) the profiles from all campaigns can best be described as influenced by industrial pollution.

CO (Fig. 3D). At altitudes above $6 \mathrm{~km}$ the $\mathrm{CO}$ mixing ratios from the different datasets are all approximately $100 \mathrm{ppbV}$ and are all within one standard deviation of the MINOS 2001 data. Below these altitudes the MINOS data are up to about 50 ppbV higher than

25 during the other campaigns with a maximum slightly above $1 \mathrm{~km}$ altitude. The EXPORT 2000 data show an almost identical profile but with lower absolute concentrations. The POLINAT-2 profile deviates below $6 \mathrm{~km}$ with much lower values between 1 and $3 \mathrm{~km}$ and an increase again towards $6 \mathrm{~km}$ altitude, where all profile are within the scatter of the MINOS data. 
In summary, according to Emmons et al. (2000) the trace gas profiles of the two campaigns conducted over Europe, MINOS 2001 and EXPORT 2000, do show the same features as other data from areas with major industrial pollution. In the case of the EXPORT 2000 campaign fresh emissions lead to high variability in the $\mathrm{NO}_{\mathrm{x}}$ data.

5 The profiles from SIL 1996 and POLINAT-2 do not show the "industrial profile features" so pronounced. However, in the free troposphere the volume mixing ratios of the trace gases were almost identical during all campaigns. From Figs. $3 \mathrm{C}$ and $3 \mathrm{D}$ it is also evident that $\mathrm{O}_{3}$ and $\mathrm{CO}$ levels in the lower troposphere over the Mediterranean Sea are markedly higher than over central Europe during the same season.

\section{$10 \quad 3.3$ Trace gas correlations}

\subsubsection{Mean correlations during the MINOS 2001 flights}

In addition to the mean VMR altitude profiles the altitude dependences of the mean correlations between $\mathrm{O}_{3}$ and $\mathrm{NO}_{\mathrm{y}}, \mathrm{O}_{3}$ and $\mathrm{CO}, \mathrm{CO}$ and $\mathrm{NO}_{\mathrm{y}}$, and $\mathrm{NO}_{\mathrm{x}}$ and $\mathrm{NO}_{\mathrm{y}}$ in $\mathrm{ppbV/ppbV}$ were calculated from the MINOS dataset containing the $10 \mathrm{~s}$ averages of

15 all flights. These correlations represent the slopes of linear regressions in the plots between two species and are to some degree representative for the origin of the sampled air masses, see below (e.g. Murphy et al., 1993).

The altitude profiles of the correlations were calculated in altitude bins of $200 \mathrm{~m}$ and in steps of $50 \mathrm{~m}$, i.e. the first correlation is calculated in the $0-200 \mathrm{~m}$ bin, the second 20 correlation in the range $50-250 \mathrm{~m}$, and so on. The expressions given for the slopes and the errors of the slopes are, for instance, given in Försterling and Kuhn (1971).

The results of the calculations are shown in the four panels of Fig. 4 as (a) the correlations themselves, (b) the $r^{2}$ value and (c) the number of experimental data points used to calculate the correlations.

$25 \Delta\left[\mathrm{O}_{3}\right] / \Delta\left[\mathrm{NO}_{\mathrm{y}}\right]$. Figure $4 \mathrm{~A}$ shows the altitude profile of the most prominent correlation between ozone and the total reactive nitrogen species $\mathrm{NO}_{\mathrm{y}}$. The $\Delta\left[\mathrm{O}_{3}\right] / \Delta\left[\mathrm{NO}_{\mathrm{y}}\right]$ data show a steady increase with altitude from values below 10 in the boundary layer up

1999

to $150-220$ in the upper troposphere at about $13 \mathrm{~km}$. However, $r^{2}$ indicates only poor correlations up to about $4 \mathrm{~km}$ altitude, whereas the data are well correlated above $4 \mathrm{~km}$.

These observed ratios fit well into the range of literature values of which a selection is summarized in Table 1. It should be noted that stratospheric ozone research predominantly revealed an almost constant $\Delta\left[\mathrm{O}_{3}\right] / \Delta\left[\mathrm{NO}_{\mathrm{y}}\right]$ ratio of $\approx 330$ in the lower stratosphere below $20 \mathrm{~km}$ and for $>10^{\circ}$ latitude on both hemispheres and of $\approx 1000$ in the tropical stratosphere for $<10^{\circ}$ latitude (Murphy et al., 1993; Fahey et al., 1996; NASA, 1993). The robustness of this ratio is explained by the similar chemical lifetimes of the two species in the lower stratosphere in combination with transport and

10 mixing processes (e.g. Murphy et al., 1993). Due to the entrainment of stratospheric air into the troposphere ratios of up to 150 to 250 have been found e.g. at the Mauna Loa Observatory (3400 m a.s.l.) and between 3-6 km altitude above Alaska (Atlas et al., 1996; Wofsy et al., 1992; Hübler et al., 1992a). Furthermore, the values of about 83 at altitudes between $5-11 \mathrm{~km}$ measured by Ridley et al. (1994) over New Mexico 15 agree well with the MINOS data of $50-100$ between $4-10 \mathrm{~km}$ altitude. Although the MINOS correlations in Fig. 4A are not very significant in the boundary layer, the data also agree well with the $\mathrm{O}_{3} / \mathrm{NO}_{y}$ slopes of approximately 10 near the surface as measured by other groups at these altitudes in photochemically aged rural air masses (e.g. Tov et al., 1997; Buhr et al., 1996; Trainer et al., 1993; Olszyna et al., 1994; Ridley et al., 20 1994).

Buhr et al. (1996) and Ridley et al. (1994) pointed out that if a correlation between ozone and $\mathrm{NO}_{\mathrm{y}}$ exists in the lower and middle troposphere the air masses are either influenced by downward mixing of upper tropospheric or lower stratospheric air and/or the air has been photochemically aged and the ratio provides a measure for the "pho-

25 tochemical age" of the air mass. Therefore, many authors have also used the slope of $\Delta\left[\mathrm{O}_{3}\right] / \Delta\left[\mathrm{NO}_{\mathrm{z}}\right]$ with $\left[\mathrm{NO}_{\mathrm{z}}\right]=\left[\mathrm{NO}_{\mathrm{y}}\right]-\left[\mathrm{NO}_{\mathrm{x}}\right]$ as an estimate for the upper limit of the ozone production efficiency in photochemically aged polluted air masses (Carpenter et al., 2000; Liu et al., 1987; Trainer et al., 1993; Olszyna et al., 1994; Tanner et al., 1998). The number of ozone molecules found per number of $\mathrm{NO}_{\mathrm{x}}$ molecules oxidized 
to $\mathrm{NO}_{\mathrm{z}}$ was found to be in the range 4 to 30 in the free troposphere in spring during the FREETEX 98 campaign over the Alps (Carpenter et al., 2000). Figure 5 shows the $\Delta\left[\mathrm{O}_{3}\right] / \Delta\left[\mathrm{NO}_{\mathrm{z}}\right]$ altitude profile inferred from the MINOS dataset which shows up to a factor of 2 higher values of about 50-80 in the free troposphere between 4-10 km over

5 the Mediterranean in summer indicating a much higher ozone production efficiency during the MINOS campaign than during the FREETEX measurements, being more in line with airborne measurements during the SOS Nashville Ozone Study 1995 of approximately 60 (Tanner et al., 1998).

$\Delta\left[\mathrm{O}_{3}\right] / \Delta[\mathrm{CO}]$. Another correlation which is often used to estimate the photochemical

10 ozone production rates during the transport of air masses is the ratio between ozone and the relatively long-lived anthropogenic tracer $\mathrm{CO}$ which has a lifetime of about 1 month in the free troposphere in summer (Chin et al., 1994, Parrish et al., 1993a). Parrish et al. (1993a), for instance, used the slope of the $\mathrm{O}_{3} / \mathrm{CO}$ regression line from several ground stations downwind from the North American emission sources to es-

15 timate the amount of photochemically produced $\mathrm{O}_{3}$ exported to the free troposphere over the North Atlantic Ocean.

The altitude profile of the $\Delta\left[\mathrm{O}_{3}\right] / \Delta[\mathrm{CO}]$ correlation during the MINOS 2001 flights is plotted in Fig. 4B. Relatively significant values of approximately 0.1 to 0.2 are found in the boundary layer. The ratio increases between 4 and $5 \mathrm{~km}$ up to values of about 1 20 which may indicate ozone production (see below). Between 5-9 km, almost no correlation is found. In line with the expected anticorrelation of the two species in the stratosphere, the ratio becomes significantly negative in the upper troposphere (e.g. Herman et al., 1999; Fischer et al., 2000). As shown in Table 2, which gives an overview of literature values, the slope of the $\mathrm{O}_{3} / \mathrm{CO}$ correlation was found to be amazingly constant in the planetary boundary layer and lower troposphere with typical values ranging from approximately 0.2 to 0.4 (McGovern et al., 1996; Parish et al., 1993a; Wofsy et al., 1992; Buhr et al., 1996; Carpenter et al., 2000; Chin et al., 1994; and references therein). This is slightly higher than the values derived from the MINOS dataset in the planetary boundary layer, but lower than the MINOS correlations of $\sim 1$ between 4

2001

$6 \mathrm{~km}$ altitude where, as indicated above, photochemical ozone production is expected (Lelieveld et al., 2002).

$\Delta[\mathrm{CO}] / \Delta\left[\mathrm{NO}_{\mathrm{y}}\right]$. A compact correlation between $\mathrm{CO}$ and $\mathrm{NO}_{\mathrm{y}}$ indicates a common source of these two combustion products in the troposphere. Wofsy et al. (1992),

5 for instance, used this ratio in connection with the $\mathrm{O}_{3} / \mathrm{CO}$ ratio to categorize plumes influenced by biomass burning. In their study $\Delta[\mathrm{CO}] / \Delta\left[\mathrm{NO}_{\mathrm{y}}\right]$ values of 120 were found in a haze layer influenced by biomass burning which was well in the range of 25350 of this ratio expected from a literature survey (Wofsy et al., 1992; and references therein). Buhr et al. (1996) found a ratio of 12 over a polluted area in the USA. While no 10 correlation is expected in the "clean" free troposphere, an anticorrelation is expected in stratospheric air masses (Hübler et al., 1992a, 1992b). Panel C of Fig. 4 shows the altitude dependence of the $\Delta[\mathrm{CO}] / \Delta\left[\mathrm{NO}_{\mathrm{y}}\right]$ ratio derived from the data of the MINOS 2001 flights. Values with $r^{2}>0.5$ are in the range of 40-50 in "layers" below $5 \mathrm{~km}$ altitude. However, it should be noted that the $\mathrm{CO}$ vs $\mathrm{NO}_{\mathrm{y}}$ ratio depends strongly on

15 single "pollution plumes" as observed during many of the MINOS 2001 flights (see below), and the average $\Delta \mathrm{CO} / \Delta \mathrm{NO}_{\mathrm{y}}$ over all flights should not be "overinterpreted". As expected, the ratio becomes strongly negative when the air is influenced by the stratosphere in the upper troposphere.

$\Delta\left[\mathrm{NO}_{\mathrm{x}}\right] / \Delta\left[\mathrm{NO}_{\mathrm{y}}\right]$. Panel $\mathrm{D}$ of Fig. 4 shows the altitude profile of the slope of the $20 \mathrm{NO}_{\mathrm{x}} \mathrm{vs} \mathrm{NO}_{\mathrm{y}}$ ratio, which - because oxides of nitrogen from combustion processes and lightning are mainly emitted as $\mathrm{NO}_{x}\left(=\mathrm{NO}+\mathrm{NO}_{2}\right)$ and are afterwards converted into $\mathrm{NO}_{y}$ species - can be used as a measure of the age of emissions. A quite common definition for the ratio in photochemically aged air is e.g. a ratio of $\Delta\left[\mathrm{NO}_{x}\right] / \Delta\left[\mathrm{NO}_{y}<0.3\right]$ (e.g. Tov et al., 1997; and references therein). The MINOS dataset shows remarkably 25 high values of $0.3-0.8$ in the lowest $500 \mathrm{~m}$ indicating fresh emissions. Values with $r^{2}>0.5$ are about 0.6 between approximately 200 and $300 \mathrm{~m}$ altitude. In the free troposphere up to about $10 \mathrm{~km}$ the correlation coefficients are generally below 0.4 . 


\subsubsection{Correlation analyses during single flights and in single plumes}

For a more detailed analysis of single plumes during the MINOS flights the correlations between the trace gases were calculated as linear least-squares-fits (a) in time intervals of $600 \mathrm{~s}$ during the flight, (b) in altitude bins of $750 \mathrm{~m}$, and (c) for dedicated

5 analyses of single plumes which could be traced back by trajectory calculations (Traub et al., this issue). For each set of calculations one case study will be discussed in the following.

The absolute values of a correlation was plotted only when the $r^{2}$-value of the calculation exceeded 0.5 . The number of available data points used for one correlation value was in the range 15-200. It is important to note that the absolute values of the correlations change with the size of the intervals used for the calculations, e.g. the altitude ranges and the time intervals. The resolution of the time and altitude correlations for these investigations was chosen to be $60 \mathrm{~s}$ and $100 \mathrm{~m}$, respectively, e.g. the altitude correlations were calculated in bins between 0-750 $\mathrm{m}$ and $100-850 \mathrm{~m}$, etc.

(a) Case Study 1 Sampling of stratospheric air along the flight track. According to the meteorological forecast for 16 August 2001 there was a region with high potential vorticity (> $2 \mathrm{PVU})$ at the $300 \mathrm{hPa}$ level $(\approx 9 \mathrm{~km}$ altitude) over north-west of Crete and partially over the Greek mainland indicating a low tropopause. Since very high tropopause heights (>15 km) prevailed during most of the campaign (see Roelofs et

20 al., this issue) and the Falcon aircraft only has a ceiling altitude of about $13 \mathrm{~km}$, the goal of MINOS flight 8 on 16 August 2001 was to try to sample stratospheric air in this region.

Due to lacking $\mathrm{CO}$ data at the beginning of the flight Fig. 6 only shows the time series of the correlation analysis between 12:15 and 14:45 UTC. Two penetrations

25 of stratospheric air masses can unambiguously be identified at 12:50-12:55 UTC and $\approx 13: 25$ UTC by high values of the $\Delta\left[\mathrm{O}_{3}\right] / \Delta\left[\mathrm{NO}_{y}\right]$ and negative values of the $\Delta\left[\mathrm{O}_{3}\right] / \Delta[\mathrm{CO}]$ ratio. During these events no correlation between $\mathrm{NO}_{\mathrm{x}}$ and $\mathrm{NO}_{\mathrm{y}}$ is observed, whereas - as expected - the $\mathrm{CO} / \mathrm{NO}_{\mathrm{y}}$ ratio is negative.

2003

Due to fresh emissions in the boundary layer the $\mathrm{NO}_{x} / \mathrm{NO}_{y}$ ratio increases during the descent at the end of the flight at approximately 14:20 UTC with the slope of $\Delta\left[\mathrm{O}_{3}\right] / \Delta\left[\mathrm{NO}_{\mathrm{y}}\right]$ at typical boundary values of $11 \pm 2$.

(b) Case study 2 Altitude profile of trace gas correlations during one flight. The ob5 jective of flight 2 of the MINOS campaign on 3 August 2001 was to observe forecasted pollution from Eastern Europe at lower flight altitudes and to capture expected outflow from the Asian monsoon region at higher altitudes, as shown in Fig. 1. The altitude dependence of the correlations measured over the northern Aegean Sea over Lesvos is shown in Fig. 7, indicating the sources of the measured trace gases.

10 In the boundary layer below $2 \mathrm{~km}$ altitude fresh emissions can unambiguously be identified by high $\Delta\left[\mathrm{NO}_{\mathrm{x}}\right] / \Delta\left[\mathrm{NO}_{\mathrm{y}}\right]$ ratios and a slightly negative slope of $\Delta\left[\mathrm{O}_{3}\right] / \Delta\left[\mathrm{NO}_{\mathrm{y}}\right]$. The $\Delta\left[\mathrm{O}_{3}\right] / \Delta[\mathrm{CO}]$ correlations at these altitudes reveal typical boundary layer values below 1 . In addition, the good correlation of $\left.\Delta[\mathrm{CO}] / \Delta \mathrm{NO}_{\mathrm{y}}\right]$ indicates common sources of these two species. Just below $3 \mathrm{~km}$ altitude the $\Delta\left[\mathrm{O}_{3}\right] / \Delta\left[\mathrm{NO}_{\mathrm{y}}\right]$ ratio increases sharply

15 in connection with negative $\Delta\left[\mathrm{O}_{3}\right] / \Delta[\mathrm{CO}]$ and $\Delta[\mathrm{CO}] / \Delta\left[\mathrm{NO}_{\mathrm{y}}\right]$ correlations. This is a strong indication for air masses of stratospheric origin being transported into the lowest part of the free troposphere below $3 \mathrm{~km}$ into a very thin layer.

Between 6 and $7 \mathrm{~km}$ altitude enhanced $\Delta\left[\mathrm{O}_{3}\right] / \Delta[\mathrm{CO}]$ ratios are observed, whereas the other species do not correlate, which may indicate $\mathrm{O}_{3}$ production during trans20 port. Other interesting features are the relatively constant and low $\Delta\left[\mathrm{O}_{3}\right] / \Delta\left[\mathrm{NO}_{\mathrm{y}}\right]$ and $\Delta\left[\mathrm{O}_{3}\right] / \Delta[\mathrm{CO}]$ ratios indicating boundary layer air, together with $\Delta\left[\mathrm{NO}_{\mathrm{x}}\right] / \Delta\left[\mathrm{NO}_{\mathrm{y}}\right]$ ratios exceeding 0.2 at approximately $11-12 \mathrm{~km}$ which, according to the forecasts in Fig. 1, may be associated with the Asian monsoon outflow.

In order to verify the origin of the air masses back trajectory calculations were per-

25 formed. Figure 8 shows the 1-min averaged trajectory analyses for flight 2 during the time when the northern vertical profile was flown between 08:30 and 09:05 UTC in steps of 5 minutes. Figure $8 \mathrm{~A}$ shows the longitude-latitude plot of the trajectories, Figure $8 \mathrm{~B}$ shows the altitudes of the trajectories as a function of the travel time of the air parcels. As expected, the trajectories in the upper troposphere originate from 
the Asian monsoon region (Fig. 8A). The trajectories ending at altitude levels of approximately $6 \mathrm{~km}$ originate from the North-American continent subsiding from 8 to $6 \mathrm{~m}$ during the previous 10 days (with enhanced $\mathrm{O}_{3} / \mathrm{CO}$ ratios) indicating that the air was being photochemically processed. Air masses with trajectories ending in the boundary layer have picked up fresh pollution from north-east Europe about one week earlier.

A notable trajectory ending at approximately $3 \mathrm{~km}$ altitude (08:59 UTC) originated from the upper troposphere at $\approx 10 \mathrm{~km}$ ten days before it crossed the Falcon flight track, giving rise to the very clear signature of stratospheric air in Fig. 7 at a remarkably low altitude. In contrast to the other trajectories in Fig. 8, this air parcel (08:59 UTC) did

10 not travel very far and stayed over the Mediterranean during the previous 10 days.

Even without further knowledge about the origin of these air masses and the meteorological situation, the stratospheric signature is unambiguous.

(c) Single plume correlations During the 14 MINOS flights numerous plumes at different flight altitudes have been captured. An overview of the correlations in the 15 single plumes is given in Table 3 . The origins of the single plumes in the different altitude regimes could be identified from the trajectory analyses described by Traub et al. (this issue).

As an example Fig. 9 shows the altitude profiles of the analyzed trace gases of MINOS flight 9 on 17 Aug. 2001, measured during a step profile flown south of Crete.

20 It should be noted that at the altitudes with large scatter of the data, i.e. at $2.4 \mathrm{~km}$, $3.7 \mathrm{~km}, 5.8 \mathrm{~km}, 8.5 \mathrm{~km}$, and $11.2 \mathrm{~km}$, the aircraft flew long flight legs at constant altitude and sampled several different air masses.

From the surface up to about $2.5 \mathrm{~km}$ the influence of polluted boundary layer air is clearly visible in the $\mathrm{NO}_{\mathrm{x}}, \mathrm{NO}_{\mathrm{y}}$, and $\mathrm{CO}$ data. The data in the free troposphere appear relatively smooth, except for an enhancement of $\mathrm{O}_{3}$ and $\mathrm{NO}_{y}$ between 6 and $7 \mathrm{~km}$ altitude. However, the most striking feature during this flight is the enhancement of $\mathrm{O}_{3}$, $\mathrm{NO}_{\mathrm{x}}$, and $\mathrm{NO}_{\mathrm{y}}$ at constant $\mathrm{CO}$ mixing ratios at altitudes between 9 and $10 \mathrm{~km}$ indicating a layer of aged air masses. Figure 10 shows the single correlation plots of the trace gas measurements in this plume. All ratios except $\Delta \mathrm{O}_{3} / \Delta \mathrm{CO}$ exhibit high corre-

$$
2005
$$

lation coefficients. It is also worth looking at the intercepts in the different plots. The $\Delta\left[\mathrm{O}_{3}\right] / \Delta\left[\mathrm{NO}_{\mathrm{y}}\right]$ fit intercepts the y axis at $(75 \pm 5)$ ppbV ozone indicating enhanced $\mathrm{O}_{3}$ in the free troposphere which may be due to photochemical production and/or mixing with stratospheric air. Due to the poor correlation between $\mathrm{O}_{3}$ and $\mathrm{CO}$ the intercept is quite 5 uncertain with values of $(34 \pm 24)$ ppbV ozone at negligible carbon monoxide. The reason for the slightly negative intercept of the $\mathrm{NO}_{x} \mathrm{vs} \mathrm{NO}_{y}$ plot is the $\pm 25 \%$ uncertainty associated with the calculation of the $\mathrm{NO}_{\mathrm{x}}$ mixing ratios (see Sect. 2).

The majority of the trajectories ending at altitudes between 9-10 km during this flight indicate that these air masses started 5 days earlier from the west coast of North 10 America $\left(\approx 52^{\circ} \mathrm{N}, 40^{\circ} \mathrm{W}\right)$ at about $11 \mathrm{~km}$ altitude, travelling over the North Atlantic Ocean to the Mediterranean region, slightly descending from north-easterly directions.

(d) Overview and comparison with earlier studies In the planetary boundary layer (PBL) the average $\Delta\left[\mathrm{O}_{3}\right] / \Delta\left[\mathrm{NO}_{\mathrm{y}}\right]$ correlations (see Sect. 3.2.1) and the data from the single plume case studies in Table 3 agree well. The derived value of about 10 in the

15 PLB from this study is in line with the findings in the literature, as given in Table 1. In the free troposphere the larger $\Delta\left[\mathrm{O}_{3}\right] / \Delta\left[\mathrm{NO}_{\mathrm{y}}\right]$ ratio is reflected in the MINOS 2001 as well as in the literature data. However, the literature values up to $\approx 11 \mathrm{~km}$ altitude show a variation in the range $20-250$ whereas the MINOS correlations vary within 20100. This could be due to the fact that the tropopause height over the Mediterranean

20 during MINOS was quite high (see Fig. 1 and Roelofs et al., this issue) and downward mixing of stratospheric ozone down to the ceiling altitude of the Falcon aircraft $(\approx 13 \mathrm{~km})$ was not very efficient. An additional explanation for the relatively low values of $\mathrm{O}_{3}$ vs $\mathrm{NO}_{y}$ in the upper troposphere during MINOS is the influence of the Asian outflow carrying relatively fresh emissions $\left(\mathrm{NO}_{x} / \mathrm{NO}_{y} \geq 0.3\right)$ in these altitudes (Scheeren et al., 25 this issue). The measured lower stratospheric value for the $\mathrm{O}_{3} / \mathrm{NO}_{\mathrm{y}}$ ratio of about 130 in Table 3 is also a little lower than expected from most of the former studies in Table 1, but in excellent agreement with the values given in Lerner et al. (1994).

The comparison of the hardly significant $\mathrm{O}_{3} / \mathrm{CO}$ slopes found during MINOS in Table 3 and former studies (Table 2) shows very good agreement in the boundary layer 
and in free tropospheric air masses. However, whereas Fischer et al. (2000) did not find any correlation in the troposphere during the STREAM 97 campaign, we find a value of $\Delta\left[\mathrm{O}_{3}\right] / \Delta[\mathrm{CO}]=2.6$ at an altitude between $10-11 \mathrm{~km}$ in one of the North Atlantic/North American plumes during MINOS. In line with the findings of Fischer et al.

5 (2000) a negative $\mathrm{O}_{3} / \mathrm{CO}$ ratio was found in stratospherically influenced air masses.

The $\mathrm{CO} / \mathrm{NO}_{\mathrm{y}}$ slopes found in single plumes in this study are well in the range of the data given in the literature, i.e. mainly positive correlations in the troposphere and an anticorrelation in the stratosphere.

In summary, it was found that the trace gas correlations calculated for the MINOS

102001 dataset, both the absolute values and the altitude profiles, are in the range of the data described in the literature. The absolute values of the correlations at different altitudes can therefore be regarded to be more typical for an altitude range than for the origin of the airmass. One possible explanation for the minor differences between the literature and MINOS 2001 data is the exceptionally high tropopause and the Asian

15 monsoon outflow events during the MINOS campaign over the Mediterranean. Furthermore, in this study the origin of stratospheric air could unambiguously be identified by correlation analyses.

\section{Summary and conclusions}

We presented mean altitude profiles of $\mathrm{NO}_{\mathrm{x}}, \mathrm{NO}_{\mathrm{y}}, \mathrm{O}_{3}$, and $\mathrm{CO}$ as measured by the DLR

20 Falcon during the MINOS 2001 campaign over the Mediterranean in August 2001, and compared with data from other aircraft campaigns. The SIL 1996 (North Atlantic flight corridor), the POLINAT-2 (North Atlantic flight corridor), and the EXPORT 2000 (central Europe) campaigns were conducted at different latitudes and seasons. It was found that at least the MINOS $\mathrm{NO}_{y}, \mathrm{O}_{3}$, and $\mathrm{CO}$ mixing ratios in the free troposphere between

25 4-8 km are very similar to those measured during the EXPORT 2000 campaign. During the MINOS campaign it was found that the main influence at these altitudes came from the North Atlantic and from North America (Lelieveld et al., 2002) with the mean

mixing ratios showing very small scatter (standard deviations). However, compared to the other campaigns the MINOS $\mathrm{O}_{3}$ and $\mathrm{CO}$ volume mixing ratios were significantly higher in the boundary layer, by about $20 \mathrm{ppbV}$ and $50 \mathrm{ppbV}$, respectively. According to Emmons et al. (2000, and references therein) the shape of the trace gas vertical 5 profiles from these two campaigns can best be described as "influenced by industrial pollution and/or biomass burning".

In Sect. 3.2 the $\Delta\left[\mathrm{O}_{3}\right] / \Delta\left[\mathrm{NO}_{\mathrm{y}}\right], \Delta\left[\mathrm{O}_{3}\right] / \Delta[\mathrm{CO}], \Delta[\mathrm{CO}] / \Delta\left[\mathrm{NO}_{\mathrm{y}}\right]$, and $\Delta\left[\mathrm{NO}_{\mathrm{x}}\right] / \Delta\left[\mathrm{NO}_{\mathrm{y}}\right]$ trace gas correlations were calculated for the MINOS 2001 campaign. It was found that, within the scatter of the data, the overall/average altitude profiles of the corre-

10 lations compared well with data from a literature survey. The analysis of the mean vertical correlation profiles as measured during MINOS 2001 does therefore not reflect the special meteorological conditions and air mass origins over the Mediterranean in summer (e.g. Lelieveld et al., 2002; and references therein) but reveals a more general feature of the troposphere which is also found in other regions in the northern hemisphere.

However, case studies of correlation analyses during single flights at different altitudes allowed the unambiguous identification of air masses influenced by the stratosphere. The origins of other plumes captured during MINOS 2001 could only be identified with the help of back trajectories. The overall analysis of the times series and

20 altitude profiles of the correlations during single flights in connection with back trajectory data revealed signatures from stratospheric air, the Asian monsoon outflow, and European pollution.

Acknowledgement. We thank the Falcon crew, the members of the DLR flight department, and the MINOS team for the good cooperation and helpful discussions.

\section{References}

Andreae, M. O., Browell, E. V., Garstang, M., Gregory, G. L., Harriss, R. C., Hill, G. F., Jacob, D. J., Pereira, M. C., Sachse, G. W., Setzer, A. W., Silvia Dias, P. L., Talbot, R. W., Torres, A. L., 
and Wofsy, S. C.: Biomass-burning emissions and associated haze layers over Amazonia, J. Geophys. Res, 93, 1509-1527, 1988.

Atkinson, R.: Atmospheric chemistry of VOCs and $\mathrm{NO}_{x}$, Atmos. Environ., 34, 2063-2101, 2000.

Atlas, E., Ridley, B., Walega, J., Greenberg, J., Kok, G., Staffelbach, T., Schauffler, S., Lind, J., Hübler, G., Norton, R., GTE PEM-West Science Team, Dlugokencky, E., Elkins, J., Oltmans, S., Mackay, G., and Kareki, D.: A comparison of aircraft and ground-based measurements at Mauna Loa Observatory, Hawaii, during GTE PEM-West and MLOPEX 2, J. Geophys. Res., 101, 14599-14612, 1996.

Buhr, M., Sueper, D., Trainer, M., Goldan, P., Kuster, B., Fehsenfeld, F., Kok, G., Shillawski, R., and Schanot, A.: Trace gas and aerosol measurements using aircraft data from the North Atlantic Regional Experiment (NARE 1993), J. Geophys. Res., 101, 29 013-29 027, 1996.

Carpenter, L. J., Green, T. J., Mills, G. P., Bauguitte, S., Penkett, S. A., Zanis, P., Schuepbach, E., Schmidbauer, N., Monks, P. S., and Zellweger, C.: Oxidized nitrogen and ozone production efficiencies in the springtime free troposphere over the Alps, J. Geophys. Res., 105, 14547-14559, 2000.

Carrol, M. A., Hastie, D. R., Ridley, B. A., Rodgers, M. O., Torres, A. L., Davis, D. D., Bradshaw, J. D., Sandholm, S. T., Schiff, H. I., Karecki, D. R., Harris, G. W., Mackay, G. I., Gergory, G. L., Condon, E. P., Trainer, M., Hubler, G., Montzka, G. I., Madronich, S., Albritton, D. L., Singh, H. B., Beck, S. M., Shipham, M. C., and Bachmeier, A. S.: Aircraft measurements

20 of $\mathrm{NO}_{x}$ over the eastern Pacific and continental United States amd implications for ozone production, J. Geophys. Res., 95, 10205-10233, 1990.

Chang, A. Y., Salawitch, R. J., Michelsen, H. A., Gunson, M. R., Abrams, M. C., Zander, R., Rinsland, C. P., Loewenstein, M., Podolske, J. R., Proffitt, M. H., Margitan, J. J., Fahey, D. W., Gao, R.-S., Kelly, K. K., Elkins, J. W., Webster, C. R., May, R. D., Chan, K. R., Abbas,

25 M. M., Goldman, A., Irion, F. W., Manney, G. L., Newchurch, M. J., and Stiller, G. P.: A comparison of measurements from ATMOS and instruments aboard the ER-2 aircraft: Tracers of atmospheric transport, Geophys. Res. Lett., 23, 2389-2392, 1996.

Chin, M., Jacob, D. J., Munger, J. W., Parrish, D. D., and Doddridge, B. G.: Relationship of ozone and carbon monoxide over North America, J. Geophys. Res., 99, 14565-14573, 1994.

Emmons, L. K., Hauglustaine, D. A., Muller, J.-F., Carroll, M. A., Brasseur, G. P., Brunner, D., Staehelin, J., Thouret, V. and Marenco, A.: Data composites of tropospheric ozone and its precursors from aircraft measurements, J. Geophys. Res., 105, 20 497-20 538, 2000.

2009

Fahey, D. W., Donnelly, S. G., Keim, E. R., Gao, R. S., Wamsley, R. C., Del Negro, L. A., Woodbridge, E. L., Proffitt, M. H., Rosenlof, K. H., Ko, M. K. W., Weisenstein, D. K., Scott, C. J., Nevison, C., Solomon, S., and Chan, K. R.: In situ observations of $\mathrm{NO}_{\mathrm{y}}, \mathrm{O}_{3}$, and the $\mathrm{NO}_{y} / \mathrm{O}_{3}$ ratio in the lower stratosphere, Geophys. Res. Lett., 23, 1653-1656, 1996.

5 Fischer, H., Wienhold, F. F., Hoor, P., Bujok, O., Schiller, C., Siegmund, P., Ambaum, M., Scheeren, H. A., and Lelieveld, J.: Tracer correlations in the northern high latitude lowermost stratosphere: Influence of cross-tropopause mass exchange, Geophys. Res. Lett., 27, 97-100, 2000.

Försterling, H.-D. and Kuhn, H.: Physikalische Chemie in Experimenten, Verlag Chemie GmbH, Weinheim/Bergstr., 51-56, 1971.

Harris, J. M., Dlugokencky, E. J., Oltmans, S. J., Tans, P. P., Conway, T. J., Novelli, P. C., and Thoning, K. W.: An interpretation of trace gas correlations during Barrow, Alaska, winter dark periods, 1986-1997, J. Geophys. Res., 105, 17267-17278, 2000.

Hauser, C.: Charakterisierung eines Messsystems zur Bestimmung der $\mathrm{NO}_{2}$ -

15 Photolysefrequenz in der Troposphäre - Labormessungen und Flugzeugmessungen, Diplomarbeit, Fachhochschule München, DLR, Oberpfaffenhofen, 2002.

Herman, R. L, Webster, C. R., May, R. D., Scott, D. C., Hu, H., Moyer, E. J., Wennberg, P. O., Hanisco, T. F., Lanzendorf, E. J., Salawitch, R. J., Yung, Y. L., Margitan J. J., and Bui, T. P.: Measurements of $\mathrm{CO}$ in the upper troposphere and lower stratosphere, Chemosphere: Global Change Science, 1, 173-183, 1999.

Hübler, G., Montzka, D. D., Norton, R. B., Murphy, P. C., Fehsenfeld, F. C., Liu, S. C., Ridley, B. A., Walega, J. G., Atlas, E., Grahek, F. E., Heidt, L. E., Merrill, J., Huebert, B. J., and Bodhaine, B. A.: Total reactive oxidized nitrogen $\left(\mathrm{NO}_{\mathrm{y}}\right)$ in the remote pacific troposphere and its correlation with $\mathrm{O}_{3}$ and CO: Mauna Loa Observatory Photochemistry Experiment 1988, J. Geophys. Res., 97, 10 427-10 447, 1992.

Hübler, G., Fahey, D. W., Ridley, B. A., Gregory, G. L., and Fehsenfeld, F. C.: Airborne measurements of total reactive odd nitrogen ( $\mathrm{NO}_{y}$ ), J. Geophys. Res., 97, 9833-9850, 1992.

Junkermann, W., Platt, U., and Volz-Thomas, A.: A photoelectric detector for the measurement of photolysis frequencies of ozone and other atmospheric molecules, J. Atmos. Chem., 8, 203-227, 1989.

Leighton, P. A.: Photochemistry of air pollution, Academic Press, New York and London, 1961.

Lelieveld, J., Berresheim, H., Borrmann, S., Crutzen, P. J., Dentener, F. J., Fischer, H., Feichter, J., Flatau, P., Heland, J., Holzinger, R., Korrmann, R., Lawrence, M., Levin, Z., Markowicz, 
K., Mihalopoulos, N., Minikin, A., Ramanathan, V., de Reus, M., Roelofs, G. J., Scheeren, H. A., Scaire, J., Schlager, H., Schultz, M., Siegmund, P., Steil, B., Stephanou, E., Stier, P., Traub, M., Warneke, C., Williams, J., and Ziereis, H.: Global air pollution crossroads over the Mediterranean, Science, 298, No. 5594, 794-799, 2002.

5 Lerner, A., Kley, D., Volz-Thomas, A., and McKenna, D. S.: Ozon-Stickoxid-Korrelationen in der Troposphäre, Berichte des Forschungszentrums Jülich, No. 3008, ISSN 0944-2952, Institut für Chemie und Dynamik der Geosphäre 2: Chemie der belasteten Atmosphäre, 1994.

Liu, S. C., Trainer, M., Fehsenfeld, F. C., Parrish, D. D., Williams, E. J., Fahey, D. W., Hübler, G., and Murphy, P. C.: Ozone production in the rural troposphere and the implications for regional and global ozone distributions, J. Geophys. Res., 92, 4191-4207, 1987.

McGovern, F. M., Jennings, S. G., O'Connor, T. C., and Simmonds, P. G.: Aerosol and trace gas measurements during the Mace Head experiment, Atmos. Environ., 30, 3891-3902, 1996.

Millán, M. M., Mantilla, E., Salvador, R., Carratal, A., Sanz, M. J., Alonso, L., Gangoiti, G., and Navazo, M.: Ozone cycles in the western Mediterranean Basin: Interpretation of monitoring data in complex terrain, J. Appl. Meteorol., 39, 487-508, 2000.

Millán, M. M., Salvador, R., Mantilla, E., and Kallos, G.: Photooxidant dynamics in the Mediterranean basin in summer: Results from European research projects, J. Geophys. Res., 102, 8811-8823, 1997.

Murphy, D. M., Fahey, D. W., Proffitt, M. H., Liu, S. C., Chan, K. R., Eubank, C. S., Kawa, S. R., and Kelly, K. K.: Reactive nitrogen and its correlation with ozone in the lower stratosphere and upper troposphere, J. Geophys. Res., 98, 8751-8773, 1993.

NASA: Reference Publication 1292, The atmospheric effects of stratospheric aircraft: Report of the 1992 models and measurements workshop, Vol. III - special diagnostic studies, M.J. Prather and E.E. Remsberg (eds.), National Aeronautics and Space Administration (NASA), Washington, DC, USA, 1993.

Olszyna, K. J., Bailey, E. M., Simonaitis, R., and Meagher, J. F.: $\mathrm{O}_{3}$ and $\mathrm{NO}_{\mathrm{y}}$ relationships at a rural site, J. Geophys. Res., 99, 14 557-14 563, 1994.

Parrish, D. D., Holloway, J. S., Trainer, M., Murphy, P. C., Forbes, G. L., and Fehsenfeld, F. C.: Export of North American ozone pollution to the North Atlantic Ocean, Science, 259, 1436-1439, 1993.

Parrish, D. D., Buhr, M. P., Trainer, M., Norton, R. B., Shimshock, J. P., Fehsenfeld, F. C., Anlauf, K. G., Bottenheim, J. W., Tang, Y. Z., Wiebe, H. A., Roberts, J. M., Tanner, R. L., Newman, L., Bowersox, V. C., Olszyna, K. J., Bailey, E. M., Rodgers, M. O., Wang, T. Berresheim, H.,

Roychowdhury, U. K., and Demerjian, K. L.: The total reactive oxidized nitrogen levels and the partitioning between the individual species at six rural sites in eastern North America, J. Geophys. Res., 98, 2927-2939, 1993.

Peleg, M., Luria, M., Setter, I., Perner, D., and Russel, P.: Ozone levels in central Israel, Israel J. Chem., 34, 375-386, 1994.

Ridley, B. A., Walega, J. G., Dye, J. E., and Grahek, F. E.: Distributions of NO, $\mathrm{NO}_{\mathrm{x}}, \mathrm{NO}_{\mathrm{y}}$, and $\mathrm{O}_{3}$ to $12 \mathrm{~km}$ altitude during the summer monsoon season over New Mexico, J. Geophys. Res., 99, 25519-25 534, 1994.

Sander, S. P., Friedl, R. R., DeMore, W. B., Ravishankara, A. R., Golden, D. M., Kolb, C. E., Kurylo, M. J., Hampson, R. F., Huie, R. E., Molina, M. J., and Moortgat, G. K.: Chemical kinetics and photochemical data for use in stratospheric modeling, supplement to evaluation 12: Update of key reactions, JPL Publication 00-3, NASA Panel for Data Evaluation, Evaluation Number 13, 8 March 2000, Jet Propulsion Laboratory, Pasadena, California, 2000.

Schlager, H., Schulte, P., Flatoy, F., Slemr, F., v. Velthofen, P., Ziereis, H., and Schumann,

15 U.: Regional nitric oxide enhancements in the North Atlantic flight corridor observed and modeled during POLINAT 2 - a case study, Geophys. Res. Lett., 26, 3061-3064, 1999.

Schumann, U.: Research on the effects of aircraft and spacecraft upon the atmosphere (Editorial), Atmos. Environ., 32, 3065-3066, 1998.

Schumann, U.: Aircraft Emissions, Encyclopedia of Global Environmental Change, Vol. 3, 20 'Causes and Consequences of Global Environmental Change, lan Douglas (ed.), 178-186, John Wiley \& Sons, Ltd, Chichester, 2002.

Schumann, U., Schlager, H., Arnold, F., Ovarlez, J., Kelder, H., Hov, O., Hayman, G., Isaksen, I. S. A., Staehelin, J., and Whitefield, P. D.: Pollution from emissions in the North Atlantic flight corridor: Overview on the POLINAT projects, J. Geophys. Res., 105, 36050-3631, 2000.

25 Singh, H. B., Chen, Y., Gregory, G. L., Sachse, G. W., Talbot, R., Blake, D. R., Kondo, Y., Bradshaw, J. D., Heikes, B., and Thornton, D.: Trace chemical measurementsfrom the northern midlatitude lowermost stratosphere in early spring: Distributions, correlations, and fate, Geophys. Res. Lett., 24, 127-130, 1997.

Tanner, R. L., Valente, R. J., and Meagher, J. F.: Measuring inorganic nitrate species with

30 short time resolution from an aircraft platform by dual-channel ozone chemiluminescence, J. Geophys. Res., 103, 22 387-22 395, 1998.

Tov, D. A.-S., Peleg, M., Matveev, V., Mahrer, Y., Seter, I., and Luria, M.: Recirculation of polluted air masses over the east mediterranean coast, Atmos. Environ., 31, 1441-1448, 
Trainer, M., Parrish, D. D., Buhr, M. P., Norton, R. B., Fehsenfeld, F. C., Anlauf, K. G., Bottenheim, J. W., Tang, Y. Z., Wiebe, H. A., Roberts, J. M., Tanner, R. L., Newman, L., Bowersox, V. C., Meagher, J. F., Olszyna, K. J., Rodgers, M. O., Wang, T., Berresheim, H., Demerjian,

$5 \quad$ K. L., and Roychowdhury, U. K.: Correlation of ozone with $\mathrm{NO}_{y}$ in photochemically aged air, J. Geophys. Res., 98, 2917-2925, 1993.

Volz-Thomas, A., Lerner, A., Pätz, H. W., Schulz, M., McKenna, D. S., Schmitt, R., Madronich, S., and Röth, E. P.: Airborne measurements of the photolysis frequency of $\mathrm{NO}_{2}$, J. Geophys. Res., 101, 18613-18627, 1996.

10 Weinheimer, A. J., Walega, J. G., Ridley, B. A., Sachse, G. W., Anderson, B. E., and Collins Jr., J. E.: Stratospheric $\mathrm{NO}_{\mathrm{y}}$ measurements on the NASA DC-8 during AASE II, Geophys. Res. Lett., 20, 2563-2566, 1993.

Wofsy, S. C., Sachse, G. W., Gregory, G. L., Blake, D. R., Bradshaw, J. D., Sandholm, S. T., Singh, H. B., Barricl, J. A., Harriss, R. C., Talbot, R., Shipham, M. A., Browell, E. V., Jacob, D. J., and Logan, J. A.: Atmospheric chemistry in the arctic and subarctic: Influence of natural fires, industrial emissions, and stratospheric inputs, J. Geophys. Res., 97, 16 731-16 746, 1992.

Wienhold, F. G., Fischer, H., Hoor, P., Wagner, V., Königstedt, R., Harris, G. W., Anders, J., Grisar, R., Knothe, M., Riedel, W. J., Lübken, F.-J., and Schilling, T.: TRISTAR - a tracer in situ TDLAS for atmospheric research, Appl. Phys., B67, 411-417, 1998.

Ziereis, H., Schlager, H., Schulte, P., Köhler, I., Marquardt, R., and Feigl, C.: In situ measurements of the $\mathrm{NO}_{\mathrm{x}}$ distribution and variability over the eastern North Atlantic, J. Geophys. Res., 104, $16021-16$ 032, 1999.

Ziereis, H., Schlager, H., Schulte, P., v. Velthoven, P. F. J., and Slemr, F.: Distributions of NO, $25 \quad \mathrm{NO}_{x}$, and $\mathrm{NO}_{y}$ in the upper troposphere and lower stratosphere between $28^{\circ}$ and $61^{\circ} \mathrm{N}$ during POLINAT 2, J. Geophys. Res., 105, 3653-3664, 2000a.

Ziereis, H., Schlager, H., Fischer, H., Feigl, C., Hoor, P., Marquardt, R., and Wagner, V.: Aircraft measurements of tracer correlations in the Arctic subvortex region during the Polar Stratospheric Aerosol Experiment (POLSTAR), J. Geophys. Res., 105, 24 305-24 313, $2000 \mathrm{~b}$.

Table 1. Survey of $\Delta\left[\mathrm{O}_{3}\right] / \Delta\left[\mathrm{NO}_{\mathrm{y}}\right]$ correlations at different altitudes from field measurements. Whenever available the $r^{2}$ are given in parentheses

\begin{tabular}{|c|c|c|c|c|}
\hline Altitude & $\Delta\left[\mathrm{O}_{3}\right] / \Delta\left[\mathbf{N O}_{\mathbf{y}}\right]$ & Area & Comment & References \\
\hline PBL & 6-10 (0.73-0.9) & Mediterranean, Israel & $\begin{array}{l}\text { photochemically aged air, rural site, no } \\
\text { correlation in fresh plumes }\end{array}$ & Peleg et al. 1994 \\
\hline PBL & $10.9(0.98)$ & Mediterranean, Israel & transported aged polluted air, $\mathrm{NO}_{\mathrm{y}}$ limited & Tov et al. 1997 \\
\hline PBL & $\approx 10$ & USA, Gulf of Maine & & Buhr et al 1996 \\
\hline PBL & no corr. & marine air, $<600 \mathrm{~m}$ & & Hübler et al. 1992b \\
\hline PBL & $\approx 11$ & US ground stations & photochemically aged air masses & Trainer et al. 1993 \\
\hline PBL & 10 & continental USA stations & & Olszyna et al. 1994 \\
\hline $2-2.5 \mathrm{~km}$ & $\approx 33$ & New Mexico & & Ridley et al. 1994 \\
\hline $2-3 \mathrm{~km}$ & $\approx 22$ & Alaska & haze layer, forest fire emissions & Wofsy et al. 1992 \\
\hline$>3 \mathrm{~km}$ & $\approx 95$ & $\begin{array}{l}\text { Mauna Loa Observatory + aircraft } \\
\text { measurements }\end{array}$ & $\begin{array}{l}\text { free troposphere, data from different } \\
\text { campaigns }>3 \mathrm{~km}\end{array}$ & Hübler et al. 1992a \\
\hline $3.4 \mathrm{~km}$ & 185 & Mauna Loa Observatory & remote free troposphere & Atlas et al. 1996 \\
\hline $3-6 \mathrm{~km}$ & $158-173$ & Alaska & "background" & Wofsy et al. 1992 \\
\hline $4.4-6.1 \mathrm{~km}$ & $167-250$ & marine and continental USA & free troposphere, marine air & Hübler et al. 1992b \\
\hline $5-11 \mathrm{~km}$ & $\approx 83$ & New Mexico & & Ridley et al. 1994 \\
\hline FT \& LS & $130 \pm 3.4(0.99)$ & England & 1990/91, summer campaigns & Lerner et al. 1994 \\
\hline LS & $\approx 185(0.97)$ & $37-57 \mathrm{deg} \mathrm{N}$ & & Singh et al. 1997 \\
\hline LS & $189-256$ & $>60 \operatorname{deg} \mathrm{N}$ & POLSTAR 1, 1997 & Ziereis et al. 2000a \\
\hline LS & $278-417$ & $>60 \operatorname{deg} \mathrm{N}$ & POLSTAR 2, 1998 & Ziereis et al. 2000a \\
\hline LS & $\approx 200-250$ & $40-90 \operatorname{deg} \mathrm{N}, 10-12 \mathrm{~km}$ alt. & & Weinheimer et al. 1993 \\
\hline LS & $\approx 200$ & $\mathrm{~N}_{2} \mathrm{O}: 170-310 \mathrm{ppbV}$ & & Chang et al. 1996 \\
\hline $\mathrm{S}$ & $\approx 1000$ & $\leq 10^{\circ} \mathrm{N} / \mathrm{S}, 50-70 \mathrm{hPa}$ & $(18-20 \mathrm{~km})$ & Fahey et al. 1996, Murphy \\
\hline & $\approx 330$ & $\geq 10^{\circ} \mathrm{N} / \mathrm{S}, 50-70 \mathrm{hPa}$ & & et al. 1993 \\
\hline
\end{tabular}


Table 2. Survey of $\Delta\left[\mathrm{O}_{3}\right] / \Delta[\mathrm{CO}]$ correlations at different altitudes from field measurements. Whenever available the $r^{2}$ are given in parentheses

\begin{tabular}{|c|c|c|c|c|}
\hline Altitude & $\begin{array}{l}\Delta\left[\mathrm{O}_{3}\right] / \Delta[\mathrm{CO}] \\
(\mathrm{ppbV} / \mathrm{ppbV})\end{array}$ & Area & Comment & References \\
\hline PBL & $0.34(0.86)$ & Mace Head, Ireland & $\begin{array}{l}\text { no biomass burning, in case of biomass } \\
\text { burning, no correlation was found. }\end{array}$ & McGovern et al. 1996 \\
\hline PBL & $-0.345 \pm 0.025(0.42)$ & Barrows, Alaska & dark period, air from Sibiria & Harris et al. 2000 \\
\hline PBL & 0.3 & North America & photochemically aged air & $\begin{array}{l}\text { Chin et al. } 1994 \\
\text { + ref's therein }\end{array}$ \\
\hline PBL & $0.22-0.29$ & Atlantic coast of Canada & & Parrish et al. 1993 \\
\hline PBL $0-0.8 \mathrm{~km}$ & $0.29(0.76)$ & Gulf of Maine, New England & & Buhr et al 1996 \\
\hline PBL $0.8-1.5 \mathrm{~km}$ & $0.32(0.50)$ & Gulf of Maine, New England & & Buhr et al 1996 \\
\hline $1.5-4.5 \mathrm{~km}$ & $0.015-0.093$ & Amazonia & biomass burning plumes & Andreae et al. 1988 \\
\hline $2-3 \mathrm{~km}$ & $\approx 0.21$ & Alaska & haze layers, forest fire plumes & Wofsy et al. 1992 \\
\hline $3-6 \mathrm{~km}$ & no corr. & Alaska & Background air & Wofsy et al. 1992 \\
\hline FT $3.58 \mathrm{~km}$ & $0.28(0.67)$ & Jungfraujoch & Freetex'98 & Carpenter et al. 2000 \\
\hline$<6.5 \mathrm{~km}$ & 0.58 & USA & increasing with altitude & Carrol et al. 1990 \\
\hline$<6.5 \mathrm{~km}$ & 0.37 & Eastern Pacific & increasing with altitude & Carrol et al. 1990 \\
\hline Troposphere & no corr. & & STREAM 97 & Fischer et al. 2000 \\
\hline Stratosphere & $\approx-24$ & & STREAM 97 & Fischer et al. 2000 \\
\hline
\end{tabular}

Table 3. Overview of the single plume events that showed correlations $\left(r^{2}>0.5\right)$ between the analyzed trace gases. The $r^{2}$ are given in parentheses. $\left({ }^{(*)} 12: 50-13: 30\right.$ UTC)

\begin{tabular}{|c|c|c|c|c|c|c|}
\hline Altitude & $\Delta\left[\mathrm{O}_{3}\right] / \Delta\left[\mathrm{NO}_{\mathrm{y}}\right]\left(\mathrm{r}^{2}\right)$ & $\Delta\left[\mathrm{O}_{3}\right] / \Delta[\mathrm{CO}]\left(\mathrm{r}^{2}\right)$ & $\Delta[\mathrm{CO}] / \Delta\left[\mathrm{NO}_{\mathrm{y}}\right]\left(\mathrm{r}^{2}\right)$ & $\Delta\left[\mathrm{NO}_{\mathbf{x}}\right] / \Delta\left[\mathrm{NO}_{\mathrm{y}}\right]\left(\mathbf{r}^{2}\right)$ & Flight \# & Origin \\
\hline PBL: $\approx 0.1 \mathrm{~km}$ & $10 \pm 1(0.91)$ & $0.22 \pm 0.02(0.63)$ & $36 \pm 2(0.83)$ & $0.19 \pm 0.003(0.97)$ & 13 & Western European Air \\
\hline PBL: $<2 \mathrm{~km}$ & $7 \pm 1(0.65)$ & --- & --- & $0.29 \pm 0.03(0.60)$ & 14 & ---"--- \\
\hline PBL: $<2 \mathrm{~km}$ & $10 \pm 1(0.56)$ & --- & --- & -- & 9 & Eastern European Air \\
\hline PBL: $<1.5 \mathrm{~km}$ & $12 \pm 1(0.57)$ & --- & --- & -- & 8 & $---"---$ \\
\hline PBL: $<1.5 \mathrm{~km}$ South & $8 \pm 1(0.51)$ & --- & --- & -- & 7 & ---"--- \\
\hline FT: 3-7 km North & $22 \pm 1(0.77)$ & $0.23 \pm 0.02(0.70)$ & $92 \pm 2(0.95)$ & --- & 7 & ----"-- \\
\hline FT: 3-7 km South & $66 \pm 4(0.86)$ & --- & --- & --- & 7 & ----"-- \\
\hline FT: $3-8 \mathrm{~km}$ & $72 \pm 6(0.54)$ & & & --- & 3 & North Atlantic Air \\
\hline FT: 6-9 km & $37 \pm 1(0.75)$ & --- & --- & $0.13 \pm 0.01(0.64)$ & 9 & Mixture: West + East \\
\hline FT: $7-10 \mathrm{~km}$ & $49 \pm 2(0.81)$ & --- & --- & --- & 10 & North American+ N. Atlantic \\
\hline FT: 6-9 km & $40 \pm 2(0.81)$ & --- & --- & --- & 13 & ---"--- \\
\hline UT: $10-11 \mathrm{~km}$ & $44 \pm 1(0.94)$ & $2.6 \pm 0.1(0.89)$ & $16 \pm 1(0.86)$ & --- & 13 & ---"-- \\
\hline UT: $9-10 \mathrm{~km}$ & $25 \pm 4(0.74)$ & --- & $12 \pm 1(0.80)$ & $0.21 \pm 0.01(0.96)$ & 9 & ---"--- \\
\hline UT: $8-11 \mathrm{~km}$ & $102 \pm 5(0.59)$ & --- & --- & $0.24 \pm 0.01(0.58)$ & 14 & ---"--- \\
\hline $\mathrm{UT}:>10 \mathrm{~km}$ & $59 \pm 2(0.73)$ & --- & --- & $0.39 \pm 0.02(0.73)$ & 1 & Monsoon Outflow \\
\hline UT: $>10 \mathrm{~km}$ & $72 \pm 2(0.80)$ & --- & --- & $0.30 \pm 0.01(0.76)$ & 2 & ---"--- \\
\hline LS: $9.4 \mathrm{~km}^{(*)}$ & $133 \pm 7(0.75)$ & $-7.1 \pm 0.5(0.64)$ & $-14 \pm 1(0.63)$ & $0.24 \pm 0.02(0.60)$ & 8 & Lower Stratospheric Air \\
\hline
\end{tabular}




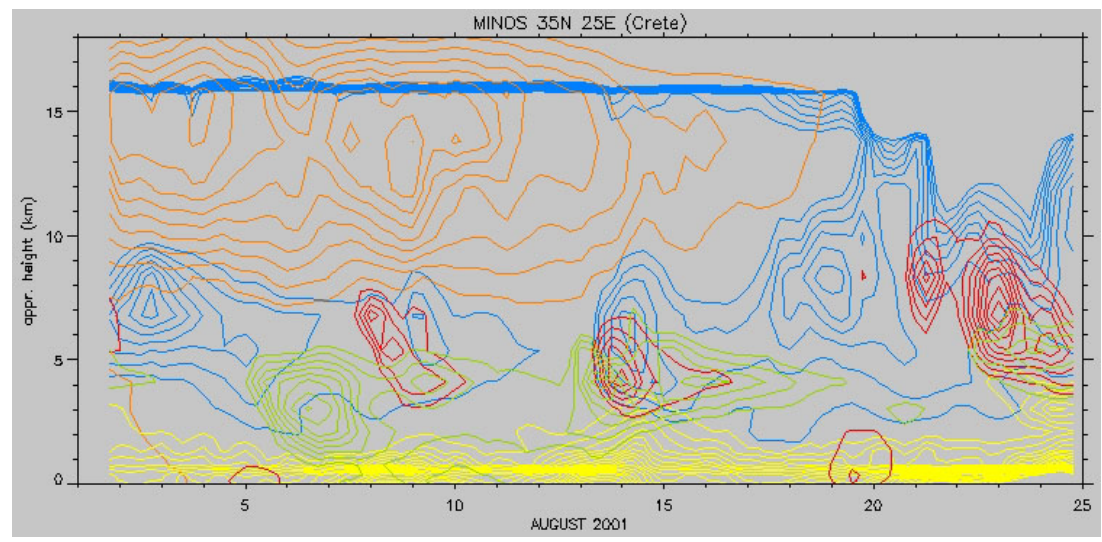

Fig. 1. Qualitative analysis of tracers originating from different regions as an altitude plot over Crete during August 2001, see Roelofs et al., this issue. Yellow indicates European tracers, blue reflects stratospheric influence, orange Asian tracers, and red and green North American and North Atlantic tracers, respectively.

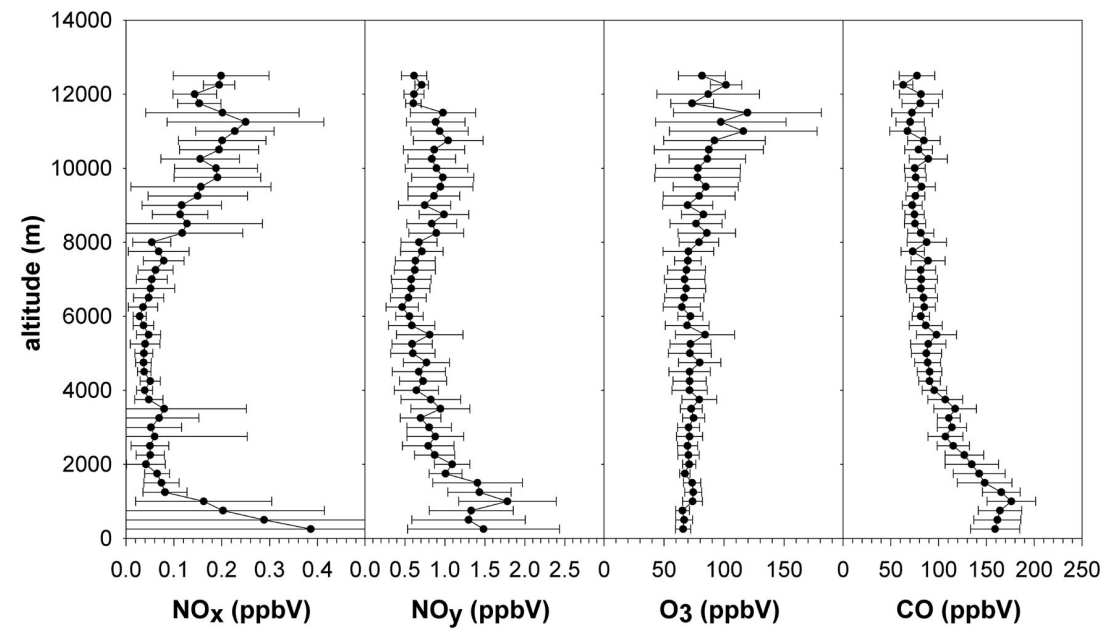

Fig. 2. Mean altitude profiles of $\mathrm{NO}_{x}, \mathrm{NO}_{y}, \mathrm{O}_{3}$, and $\mathrm{CO}( \pm 1 \sigma)$ measured during the MINOS campaign in August 2001 over the Mediterranean Sea. 

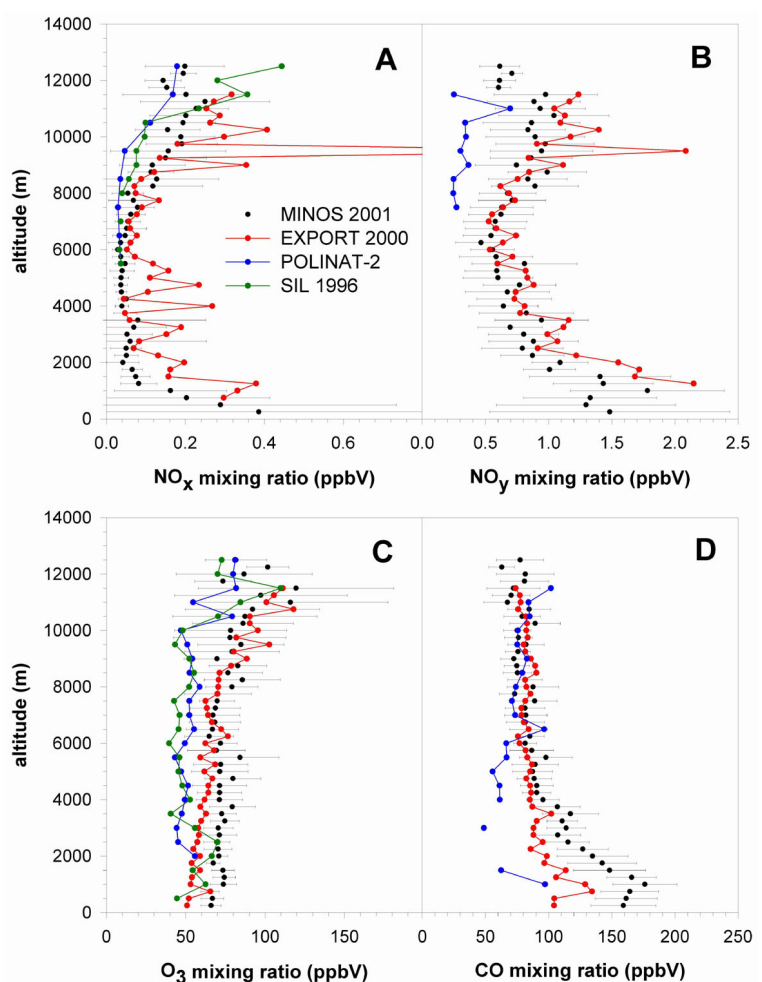

Fig. 3. Comparison of trace gas altitude profiles measured during the MINOS campaign with data from the EXPORT 2000, POLINAT-2, and SIL 1996 campaigns, see text for details.
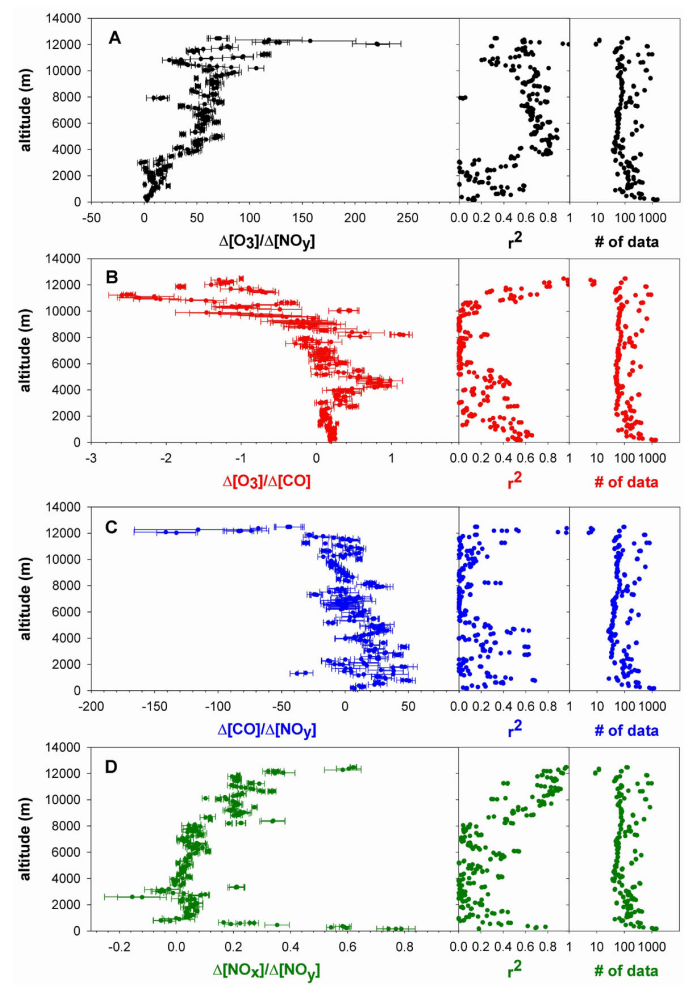

Fig. 4. Mean altitude profiles of the trace gas correlations calculated from the 14 MINOS 2001 flights over the Mediterranean. To the right the $r^{2}$-value and the number of data points used for the calculation are given for the different altitudes. 


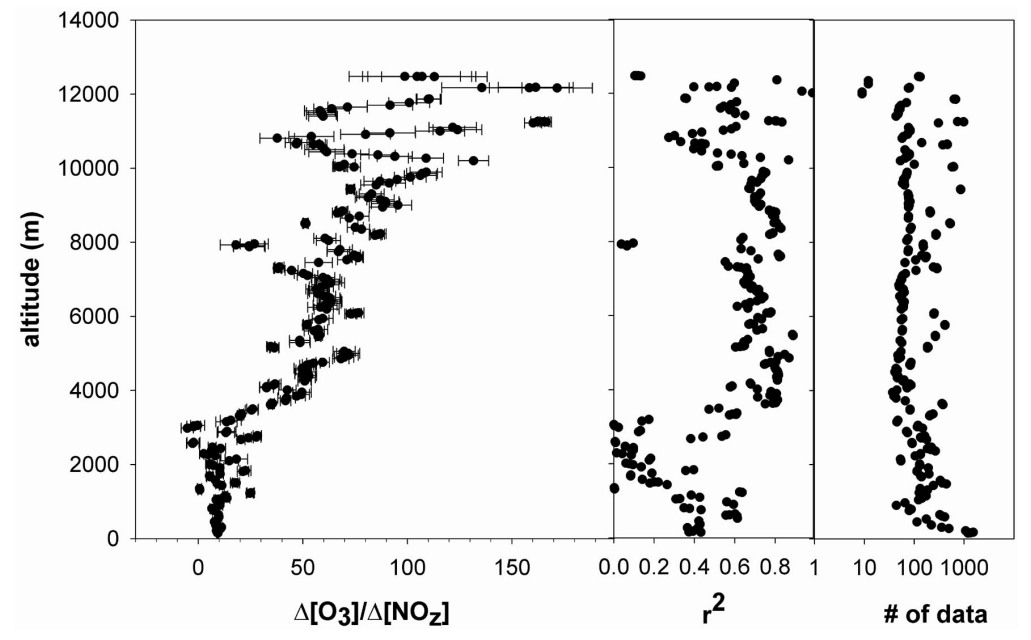

Fig. 5. Altitude profile of the $\mathrm{O}_{3} \mathrm{vs}_{\mathrm{NO}}\left(=\mathrm{NO}_{\mathrm{y}}-\mathrm{NO}_{\mathrm{x}}\right)$ correlation calculated from the MINOS dataset. To the right the $r^{2}$-value and the number of data points used for the calculation are given for the different altitudes.

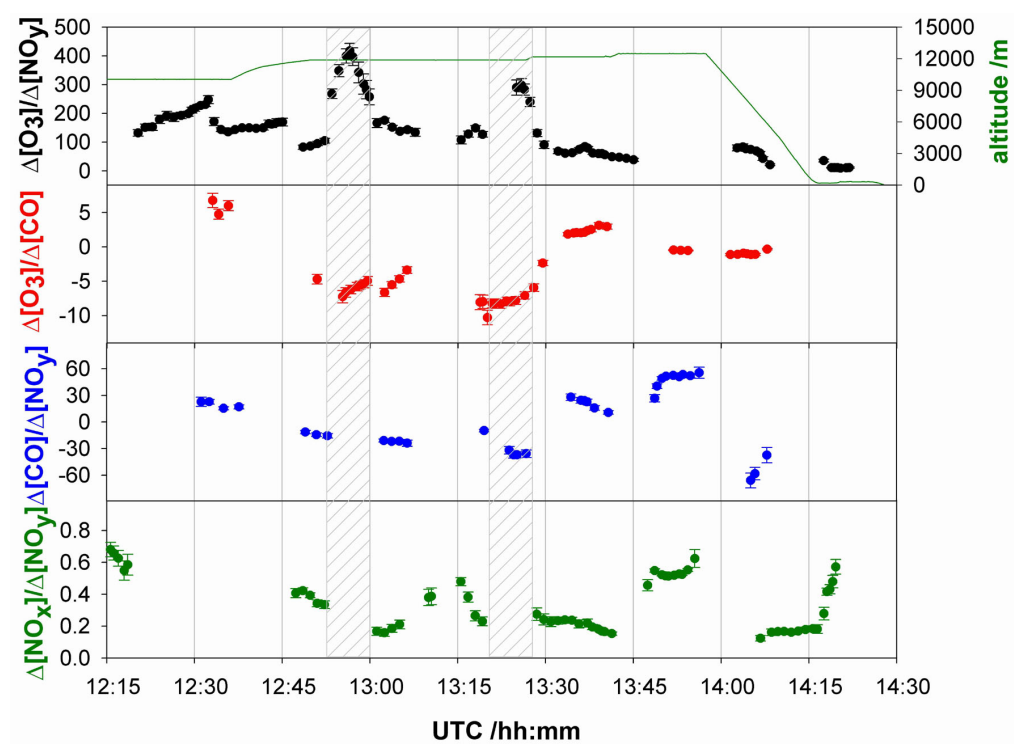

Fig. 6. Time series of the correlations calculated during the second part of MINOS flight 8 (16 August 2001) over the north-western Aegean Sea with the aim to sample the stratosphere at high altitude levels of the flight. The time intervals in which stratospheric air was sampled are highlighted. 


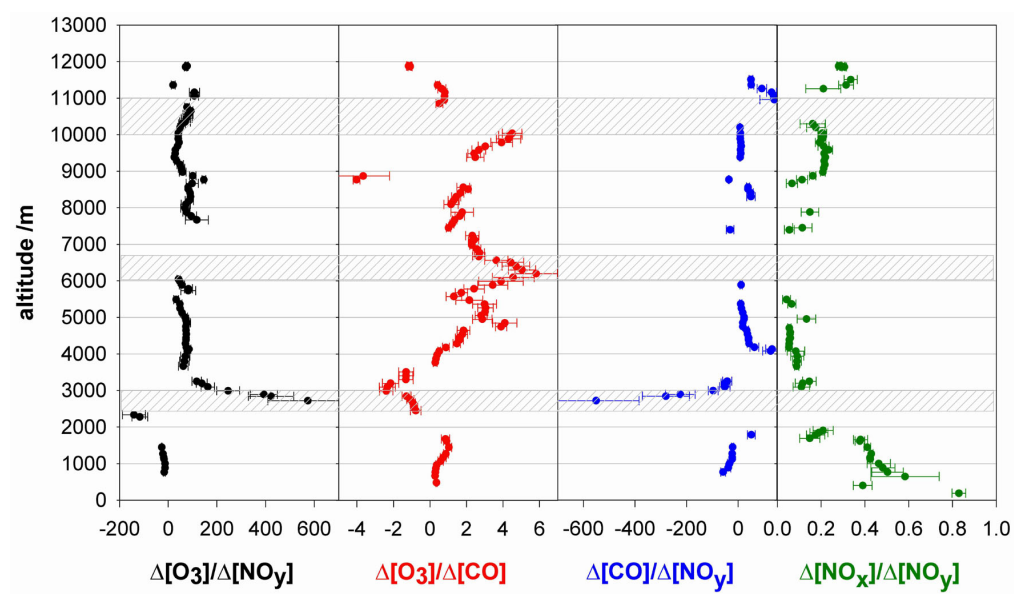

Fig. 7. Altitude profiles of the correlations during the northern vertical profiles of MINOS flight 2 (3 August 2001) over the northern Aegean Sea.
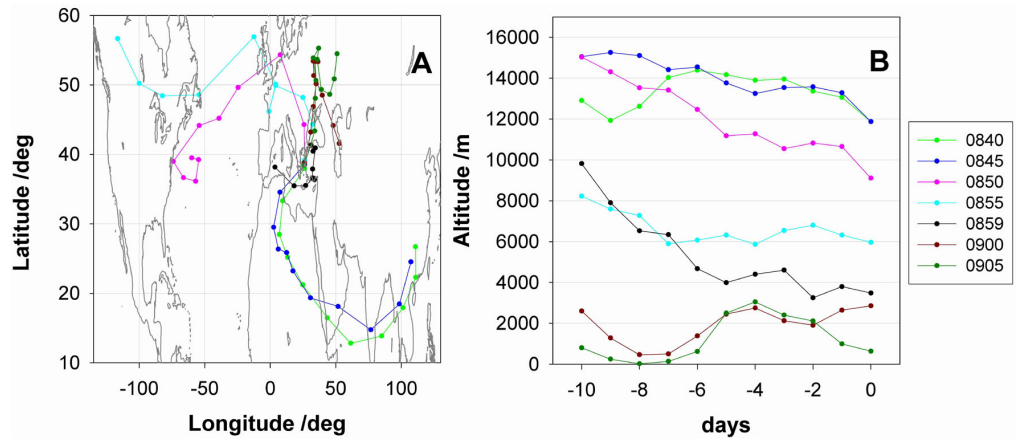

Fig. 8. Longitude-latitude plot of the trajectories for the northern profile of MINOS flight \# 2 on 3 August 2001 (A). The trajectories end along the flight path of the Falcon aircraft. (B) shows the altitudes of these trajectories as a function of travel time. 


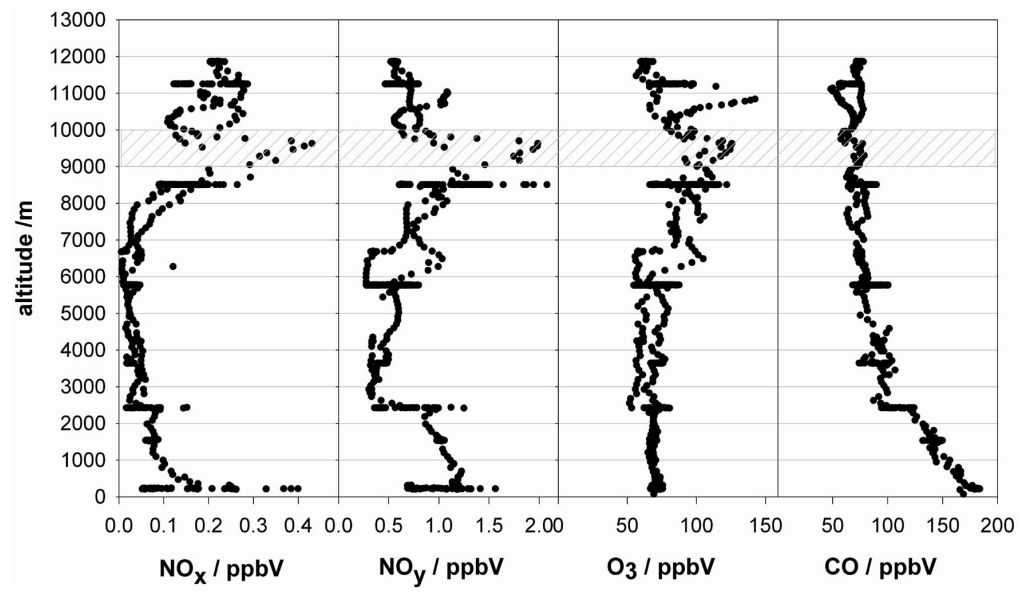

Fig. 9. Altitude dependence of the measured trace gas mixing ratios during MINOS flight 9 (17 August 2001). A remarkable feature is the layer between $9-10 \mathrm{~km}$ indicating aged air masses, see text for details.
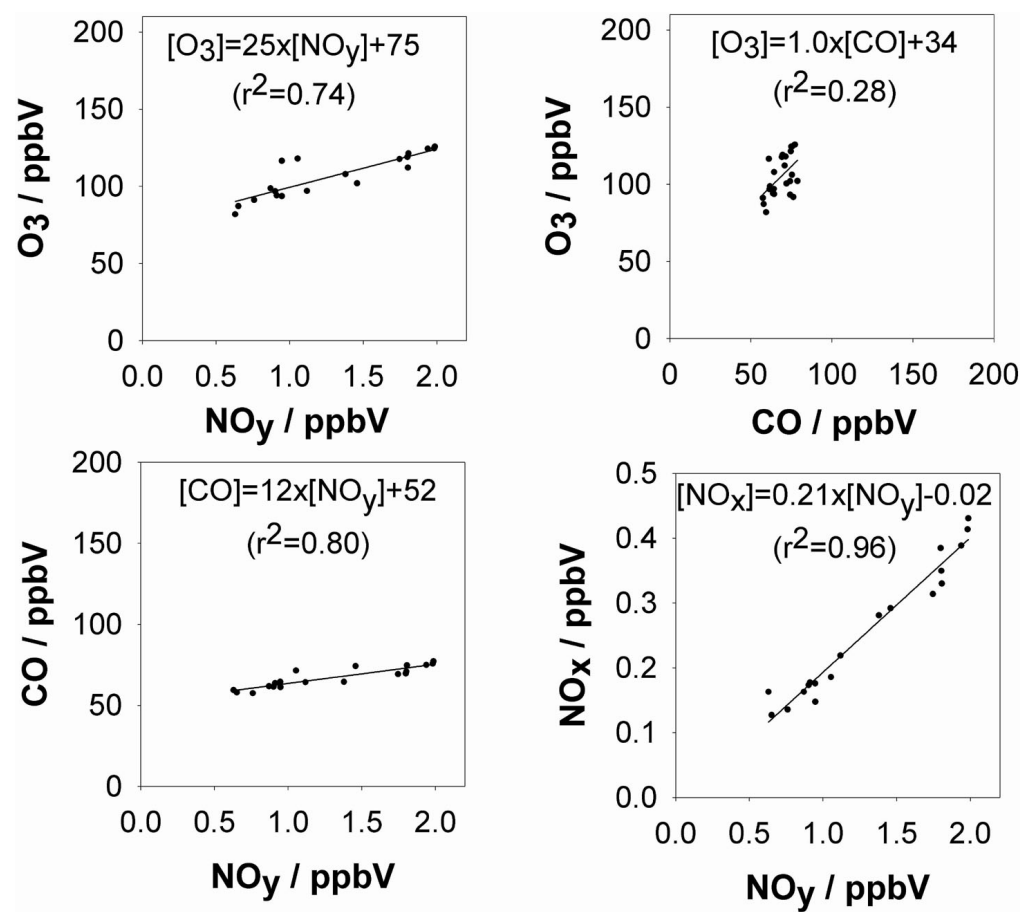

Fig. 10. Trace gas correlations for the plume between 9 and $10 \mathrm{~km}$ altitude of MINOS flight 9 (17 August 2001), see Fig. 9. All plots show high correlations except for $\Delta\left[\mathrm{O}_{3}\right] / \Delta[\mathrm{CO}]$. The uncertainties of the slopes and the intercepts are given in Table 3 and in the text, respectively. 